\title{
Nursing Student Interprofessional Simulation Increases Empathy and Improves Attitudes on Poverty
}

Kathryn Phillips

Fairfield University, kphillips1@fairfield.edu

Anka Roberto

\section{Sandra Salmon}

Valerie Smalley

Follow this and additional works at: https://digitalcommons.fairfield.edu/nursing-facultypubs

Copyright (c) 2020 Informa UK Limited

This is an Accepted Manuscript of an article published by Taylor \& Francis in Journal of Community Health Nursing on January 6, 2020, available online: http://www.tandfonline.com/ 10.1080/07370016.2020.1693095.

\section{Peer Reviewed}

\section{Repository Citation}

Phillips, Kathryn; Roberto, Anka; Salmon, Sandra; and Smalley, Valerie, "Nursing Student Interprofessional Simulation Increases Empathy and Improves Attitudes on Poverty" (2020). Nursing and Health Studies Faculty Publications. 235.

https://digitalcommons.fairfield.edu/nursing-facultypubs/235

\section{Published Citation}

Phillips, Kathryn E., Anka Roberto, Sandra Salmon, and Valerie Smalley. "Nursing Student Interprofessional Simulation Increases Empathy and Improves Attitudes on Poverty." Journal of Community Health Nursing 37, no. 1 (2020): 19-25. https://doi.org/10.1080/07370016.2020.1693095

This item has been accepted for inclusion in DigitalCommons@Fairfield by an authorized administrator of DigitalCommons@Fairfield. It is brought to you by DigitalCommons@Fairfield with permission from the rightsholder(s) and is protected by copyright and/or related rights. You are free to use this item in any way that is permitted by the copyright and related rights legislation that applies to your use. For other uses, you need to obtain permission from the rights-holder(s) directly, unless additional rights are indicated by a Creative Commons license in the record and/or on the work itself. For more information, please contact digitalcommons@fairfield.edu. 
Title: Nursing student interprofessional simulation increases empathy and improves attitudes on poverty

\section{Authors:}

Kathryn E. Phillips, PhD, MS, MA, APRN

Associate Professor

Fairfield University

1073 N. Benson Rd., Fairfield, CT 06824

Email: kphillips1@fairfield.edu

Anka Roberto, DNP, APRN, PMHNP-BC, MPH

Assistant Professor

University of North Carolina Wilmington

601 S. College Rd.

Wilmington, NC 28403

Email: robertoa@uncw.edu

Sandra Salmon, RN, MSN

Case Manager

VA Connecticut Healthcare System

950 Campbell Ave. West Haven, CT 06516

Sandra.salmon@va.gov

Valerie Smalley, RN, BSN

Case Manager

VA Connecticut Healthcare System

950 Campbell Ave. West Haven, CT 06516

Valerie.smalley@va.gov 


\begin{abstract}
Nursing student interprofessional simulation increases empathy and improves attitudes on poverty.

Poverty is increasing and it has adverse effects on health. Nurses need to understand how to help patients in poverty meet health goals within interprofessional teams. Nursing students and Veteran's Affairs employees, consisting of patient care and support staff, were recruited for an interprofessional poverty simulation. Prior to and directly following the simulation, participants were asked to complete the Attitudes about Poverty and Poor People (APPP) scale, the Toronto Empathy Questionnaire (TEQ), and the Self Reflection and Insight Scale (SRIS). Scores on the APPP and TEQ improved. The SRIS results had no significant changes. Interprofessional simulation positively impacts attitudes towards poverty and empathy in nursing students and health professionals.
\end{abstract}




\section{Background}

As of 2018, there were 38.1 million people living in poverty in the United States or $11.8 \%$ of the population (United States Census Bureau, 2019). This number is even greater when considering world poverty, with estimates indicating 780 million people are living below the international poverty line with nearly $11 \%$ of the world's population affected by extreme poverty (United Nations, 2019). The international poverty line is defined as living on less than US\$1.90 per person per day with most people living in poverty residing in sub-Saharan Africa and Southern Asia (United Nations, 2019).

Furthermore, poverty and poor health are related. Disability and poor health can mean the inability to work. For example, those with a disability $(24.9 \%)$ have poverty rates that are more than double those without a disability (10.1\%) (United States Census Bureau, 2018). Meanwhile, individuals living in poverty experience conditions that may cause poor health, such as overcrowding or poor sanitation, that create susceptibility to airborne diseases like tuberculosis and respiratory infections (Health Poverty Action, 2015). The link between poverty and health can be even more challenging for the young who have the highest rates of poverty of any age group (17.5\% of those under age 18) (United States Census Bureau, 2018). Even when young individuals are able to overcome the challenges of being raised in poverty, and demonstrated social resilience, the odds of health problems are much higher. Research indicates poor adolescents have higher physiological and/or behavioral stressors putting them at risk for many chronic diseases like hypertension and diabetes (Brody, Yu, Chen, Miller, Kogan, \& Beach, 2013).

For nurses to effectively assist patients in poverty with health care we need to train nursing students to understand the challenges those in poverty face. One of the best ways to 
prepare nursing students to better care for individuals in poverty is to teach nursing students how to work in interdisciplinary teams (Hu, Cox, Nyhof-Young, 2018; Johnson \& Howell, 2017). The Interprofessional Education Collaborative (IPEC) (2011) report on competencies for collaborative practice stresses the importance of health care disciplines to come together for training. The climate of healthcare is changing and there is a need for nurses to receive training that includes working within interprofessional teams to address healthcare issues such as poverty. By bridging the divide in health education, teams of healthcare providers can learn to work together to provide integrated care, providing better care for patients.

The attitude a health care provider brings to their work can affect their behavior with a patient (Ajzen, 2001). Negative attitudes among nurses toward those in poverty could result in poor quality nursing care. A survey of nursing students' attitudes toward those in poverty indicated those who had diverse personal experiences with poverty had more favorable attitudes (Sword, Reutter, Meagher-Stewart, \& Rideout, 2004). Additionally there is evidence that it's possible to change nursing students' attitudes about poverty through simulated poverty experiences (Noone, Sideras, Gubrud-Howe, Voss, \& Mathews, 2012; Patterson \& Hulton, 2012; Yang, Ratliff Woomer, Agbemenu, Williams, 2014). The purpose of this study was to determine if an interprofessional poverty simulation could change attitudes toward those in poverty, levels of empathy, as well as self-reflection and insight among nursing students and VA employees.

\section{Methods}

\section{Design}

Subjects in this study were recruited from a school of nursing and a local Veteran's Affairs (VA) healthcare system. The school of nursing and the VA healthcare system have a partnership and decided to collaborate on this simulation to provide an interprofessional 
experience for students and VA staff. Students in the school of nursing were required to attend the simulation as part of a clinical course and were invited to participate in the study portion of the simulation. Employees of the VA healthcare system were recruited via email and offered continuing education units (CEUs) if they attended the simulation. Faculty of the first author's institution, administrators from the first author's institution and the VA healthcare system, as well as local government officials were also invited to attend and many chose to participate in the simulation. Participation in the research portion of the event was not a requirement for any of the participants of the simulation (students, VA staff, or others).

Volunteer staff was recruited from local organizations to help run the simulation by playing the role of community liaisons that assist individuals in poverty (e.g. food banks, shelters, aid agencies, etc.). Training of the volunteer staff was completed in two training days. Simulation participants attended a 6 hour simulation day consisting of an orientation session, a 3 hour simulation experience, and debriefing sessions after the completion of a 15 minute simulated week. Each participant was assigned a role in The Community Action Poverty Simulation $\$ kit from the Missouri Community Action Network (2016). The roles place participants in a family that lives in poverty in which they must live in the assigned role for one simulated month divided into four separate weeks. Participants live each week for 15 minutes in real time and spend thirty minutes in a debriefing session as whole community in between the 4 15 minute sessions. The simulated experience as whole took three and a half hours. Participants experience what it is like to utilize social services, navigate limited resources in their community and make decisions about what to do when there is not enough money to pay bills, such as food, rent, medicine, utilities, co-pays for doctor appointments, daycare, transportation, and education. An example listed in Table I of one of the many roles that participants may get assigned to. 
Table I: Example of a Participant Role

\begin{tabular}{|c|c|c|c|}
\hline & $\begin{array}{c}\text { Poverty Simulation } \\
\text { Role }\end{array}$ & $\begin{array}{c}\text { Demographic } \\
\text { Information of role: } \\
\text { (environment, age, } \\
\text { living situation) }\end{array}$ & $\begin{array}{c}\text { Objective/Goal of } \\
\text { scenario with barriers } \\
\text { in place }\end{array}$ \\
\hline $\begin{array}{c}\text { Simulated Week } 1 \\
\text { (first } 15 \text { min real time } \\
\text { block) }\end{array}$ & Pedro & $\begin{array}{l}21 \text { year old male } \\
\text { whose father is } \\
\text { incarcerated and } \\
\text { mother is a full time } \\
\text { working mom, Pedro } \\
\text { has } 2 \text { siblings } \\
\text { (younger ages } 8 \text { and } \\
\text { 4). Pedro is attending } \\
\text { a community college } \\
\text { and working part time } \\
\text { to help support the } \\
\text { family. }\end{array}$ & $\begin{array}{l}\text { Pedro must attend } \\
\text { school all week while } \\
\text { his mother is at home, } \\
\text { his } 8 \text { year old sibling } \\
\text { becomes ill at school. } \\
\text { Pedro and his family } \\
\text { do not have a care and } \\
\text { must take public } \\
\text { transportation. Pedro } \\
\text { and his mother must } \\
\text { work together to care } \\
\text { for his } 8 \text { year old } \\
\text { brother while he is ill. }\end{array}$ \\
\hline $\begin{array}{l}\text { Simulated Week } 2 \\
\text { (second } 15 \text { min real } \\
\text { time block) }\end{array}$ & Pedro & & $\begin{array}{l}\text { Pedro missed school } \\
\text { last week or mom } \\
\text { missed work } \\
\text { (depending on what } \\
\text { they chose to do with } \\
8 \text { year old sibling). } \\
\text { Pedro either falls } \\
\text { behind on school } \\
\text { work or does not have } \\
\text { enough food this } \\
\text { week because moms } \\
\text { lack of wages. }\end{array}$ \\
\hline $\begin{array}{c}\text { Simulated Week } 3 \\
\text { (third } 15 \text { min real time } \\
\text { block) }\end{array}$ & Pedro & & $\begin{array}{l}\text { Pedro and his family } \\
\text { lose housing b/c } \\
\text { moms wages cannot } \\
\text { pay rent for the third } \\
\text { time this month. The } \\
\text { family is now living } \\
\text { in a shelter }\end{array}$ \\
\hline $\begin{array}{c}\text { Final Week } 4 \text { (fourth } \\
15 \text { min real time } \\
\text { block) }\end{array}$ & Pedro & & $\begin{array}{l}\text { Pedro dropped out of } \\
\text { college b/c of housing } \\
\text { and lack of support } \\
\text { and the need to stay } \\
\text { with younger siblings } \\
\text { when mom has to } \\
\text { return to work. }\end{array}$ \\
\hline
\end{tabular}


The Promoting Excellence And Reflection Learning in Simulation (PEARLS) Healthcare Debriefing tool (C), was used by simulation faculty between each 1 week interval (Bajaj et al., 2018). The PEARLS method uses five steps, which allowed participants to discuss their lived experiences, barriers that were faced and potential solutions that could assist those living in poverty (see Table II).

Table II: PEARLS Debriefing Tool

\begin{tabular}{|c|c|c|c|}
\hline & Objective & Task & Phrase Used \\
\hline 1) Setting the Scene & $\begin{array}{l}\text { Create a safe } \\
\text { context for } \\
\text { learning }\end{array}$ & $\begin{array}{l}\text { State the goal of } \\
\text { debriefing; } \\
\text { articulate the basic } \\
\text { assumption }\end{array}$ & $\begin{array}{l}\text { "We're going to } \\
\text { spend the next } 30 \\
\text { minutes talking } \\
\text { through your lived } \\
\text { experience and } \\
\text { how that impacts } \\
\text { you as a healthcare } \\
\text { provider". }\end{array}$ \\
\hline 2) Reactions & Explore feelings & $\begin{array}{l}\text { Solicit Initial } \\
\text { reactions \& } \\
\text { emotions }\end{array}$ & $\begin{array}{l}\text { "I'm curious what } \\
\text { it was like being } \\
\text { Pedro in this } \\
\text { scenario, what } \\
\text { feelings came up } \\
\text { for you". }\end{array}$ \\
\hline 3) Descriptions & Clarify facts & $\begin{array}{l}\text { Develop shared } \\
\text { understanding of } \\
\text { the case }\end{array}$ & $\begin{array}{l}\text { "Please share with } \\
\text { us what Pedro had } \\
\text { going on this week } \\
\text { in the simulation, } \\
\text { what were some } \\
\text { barriers/hurdles } \\
\text { and what were } \\
\text { some protective } \\
\text { factors or things } \\
\text { that may have been } \\
\text { helpful"? }\end{array}$ \\
\hline 4) Analysis & $\begin{array}{l}\text { Explore variety of } \\
\text { performance } \\
\text { domains }\end{array}$ & $\begin{array}{l}\text { Assess learner } \\
\text { self-assessment, } \\
\text { focus facilitation } \\
\text { and encourage } \\
\text { information } \\
\text { sharing. }\end{array}$ & $\begin{array}{l}\text { "Is there anything } \\
\text { else that others } \\
\text { would like to add } \\
\text { to the experience } \\
\text { of week 1"? }\end{array}$ \\
\hline 5) Application/Summary & $\begin{array}{l}\text { Identify take } \\
\text { aways }\end{array}$ & Learner centered & $\begin{array}{l}\text { "Overall what is } \\
\text { one take away that }\end{array}$ \\
\hline
\end{tabular}




\begin{tabular}{|l|l|l|}
\hline & & \\
& & $\begin{array}{l}\text { you gained from } \\
\text { this experience"? } \\
\text { "What will you do } \\
\text { differently in your } \\
\text { role as a healthcare } \\
\text { provider"? }\end{array}$ \\
\hline
\end{tabular}

(Bajaj et al., 2018).

Those participating in the study portion of the simulation were asked to fill out pre and post simulation data collection instruments. The institutional review board (IRB) at the first author's institution approved the study. All participants enrolled in the study provided written informed consent.

\section{Measures}

Participants were asked to complete the Attitudes about Poverty and Poor People (APPP) scale, a 37 item measure with a 5 point Likert scale (Strongly agree, agree, neutral, disagree, strongly disagree) to assess perceptions on poverty (Atherton \& Gemmel, 1993). The Cronbach alpha for the form is 0.93 showing high reliability (Atherton \& Gemmel, 1993). It has been tested on social work, business and sociology college students (Atherton \& Gemmel, 1993).

The second measure participants completed was the Toronto Empathy Questionnaire (TEQ), a 16 item measure with a 5 point Likert scale (never, rarely, sometimes, often, always) designed to assess empathy from an emotional perspective (Spreng, McKinnon, Mar, \& Levine, 2009). The scale was tested on college students in a psychology course, showing good reliability with a Chronbach alpha of 0.85 (Spreng et al., 2009). It also showed good correlation with the Empathetic Concern subscale of the Interpersonal Reactivity Index (IRI) at $r=0.74, p>0.001$ (Spreng et al., 2009).

The third measure participants completed was the self-reflection and insight scale (SRIS), a 20 item measure that is scored on a 6 point Likert scale from disagree strongly to agree 
strongly (Grant, Franklin, \& Langford, 2002). The scale has three subscales: engagement in selfreflection (ESR), need for self-reflection (NSR), and insight (I). Testing has indicated a high degree of internal consistency for the subscales with ESR having a Cronbach alpha of 0.83, NSR 0.87, and I 0.85 (Roberts \& Stark, 2008). Finally, participants answered a number of open ended questions.

\section{Data Analysis}

Data were analyzed using Statistical Package for the Social Sciences (SPSS) 22®. Means and standard deviations were calculated for ratio level demographic data, while chi-square was used to assess categorical demographic data. A comparison of demographics was conducted on the two main groups in the study (hospital staff and nursing students). A t-test was used to compare age and chi-square was used to compare marital status, gender, ethnicity and history of living in poverty between the two main groups.

Paired sample t-tests were used to compare pre and post test scores for each of the three measures (APPP, SRIS, and TEQ). Significance was set at $\mathrm{p}<0.05$.

\section{Results}

\section{Sample Characteristics}

On the day of the event, 117 individuals consented to participate in the study. Of these 117, there were complete pre and post simulation measures for 75 individuals and another 9 individuals who were missing 1 or 2 questions on one of the survey measures. For these 9 cases, the pre or post survey measure value was used for imputation in place of the item missing.

The final sample for the study consisted of 84 individuals, including 45 VA hospital staff, 31 nursing students, and 8 other participants (e.g. politicians, nursing faculty, local public interested in participating, etc.). The VA hospital staff consisted of a variety of disciplines 
including but not limited to nurses, physicians, dieticians, social workers, physical therapists, police officers, administrators, researchers, and food service workers. The sample was primarily female $(84.1 \%)$ and Caucasian (79.8\%) with $12 \%$ reporting they had lived in poverty at some point in their lives. The average age was 38.72 (SD 13.51) years with a range of 21 to 65 years. Please see Table III for demographic information on the two main groups.

Table III: Demographics

\begin{tabular}{|l|l|l|l|l|l|}
\hline & $\begin{array}{l}\text { Average Age } \\
\text { in Years }\end{array}$ & Female & Caucasian & Married/Committed & Percent that \\
& & & & & Ever Lived \\
in Poverty
\end{tabular}

Demographics for the VA staff and student nurses were compared. Significant differences were found for age $(\mathrm{p}<0.01)$ and marital status $(\mathrm{p}<0.01)$. All other demographic variables (gender, ethnicity and history of living in poverty) showed no significant differences between these two groups.

\section{Quantitative Analysis}

For the entire sample $(\mathrm{n}=84)$, the APPP scale showed a significant $(\mathrm{t}=-2.218, \mathrm{p}<0.05)$ increase from pretest (121.17 (SD 11.73)) to posttest (123.05 (SD 11.07)). The TEQ significantly $(\mathrm{t}=-11.382, \mathrm{p}<0.01)$ increased from $46.6(\mathrm{SD} 5.53)$ at the pretest to $51.17(\mathrm{SD} 6.39)$ at the posttest. There was no significant $(\mathrm{t}=1.083, \mathrm{p}=0.282)$ change from the pre $(42.74(\mathrm{SD} 8.8))$ to post test (42.1 (SD 8.9)) for the SRIS scale. 


\section{Discussion}

At some point in their career, it is likely that nurses will care for patients living in poverty. Learning how to work within interprofessional teams is an effective way to deliver healthcare and an essential of baccalaureate education according to the American Association of Colleges of Nursing (AACN) (2008). The poverty simulation experience described in this study allowed a large group of interdisciplinary healthcare workers to come together and learn about the barriers that exist when living in poverty hands on. Results indicate that it is possible to positively change individuals' attitudes about those living in poverty as well as improve their empathy levels through an inter-professional poverty simulation experience.

Findings of this study corroborate prior work using poverty simulation with nursing students, which showed improved attitudes on poverty with simulated poverty experiences (Noone et al., 2012; Patterson \& Hulton, 2011; Turk \& Colbert, 2018; Yang et al., 2014). This study builds on prior work by providing the simulation experience within an interprofessional poverty simulation experience that has benefits for both healthcare workers and nursing students. When comparing scores on the attitudes toward those in poverty form (APPP), participants in this study had higher mean scores at both the pretest (121.17 (SD 11.73)) and posttest (123.05 (SD 11.07)) compared to sociology and social work students (119.65 (SD 21.97)) from a prior study by Atherton and Gemmel (1993). The higher scores found in this study may be related to the sample of nursing students, which were recruited from a Jesuit University where issues of social justice are part of the college experience both in and out of the classroom, making the APPP scores more robust. This theory is supported by a poverty simulation study that utilized virtual simulation training with nursing students stated that in order for the benefit of the 
simulation experience to stick, social justice issues needed to be integrated into every part of the curriculum (Menzel, Willson, \& Doolen, 2014).

Learning about poverty in an academic setting may have more impact on attitudes toward poverty than real-life exposure, according to a study on nursing students attitudes toward individuals in poverty (Reutter, Sword, Meagher-Stewart, \& Rideout, 2004). Nursing students who had more positive attitudes toward the poor were more likely to choose the structural reason (a poor environment) over other reasons such as the behavioral (personal reasons such as unhealthy eating), drift (poor health results in poverty) or myth (statistical bias) reasons for the link between poverty and health (Reutter et al., 2004). With the change in attitude toward those in poverty, the participants of this study may be better prepared to explain the structural link between poverty and health. They may also have more compassion for their patients' lack of health behaviors because they understand the day-to-day challenges faced by those who are struggling to obtain food and shelter. Individuals in poverty may not have the time, energy, resources, or physical ability to address the health concerns these providers are trying help them with.

In this study we also saw significant increase in empathy as measured by the TEQ. As far as the authors are aware, this is the first study of nursing students to utilize a measure of empathy in a poverty simulation study. Prior work has shown changes increases in empathy of nursing student participating in poverty simulation through qualitative responses (Hellman, Cass, Cathey, Smith, \& Hurley, 2018; Loomis \& De Natale, 2017; Turk \& Colbert, 2019; Yang et al., 2014). Utilizing poverty simulation may be an effective way to increase empathy in students, which could translate into enhanced clinical care of patients one study utilizing poverty simulation has shown (Yang et al., 2014). 
The final measure collected on participants, the SRIS, did not show a significant change from pre to post test. Although participants were better able to understand the struggles of individuals in poverty, they may not have taken the time to reflect on how it impacts their own life. They may be experiencing the change in attitude and empathy from an outside stance rather than having integrated the experience through review of their prior exposure, thoughts and beliefs on the subject. Perhaps if participants were asked to reflect and journal on the experience after the simulation, it may have increased the ability to self-reflect on the experience and increase their scores on the SRIS. As reported by prior work poverty simulation for nursing students that used reflective journaling indicates students have enhanced self-awareness with the ability to examine their beliefs and prejudices as well as an increased understanding of social justice issues with themes supporting the need to take action (Hellman et al., 2018). It may also be possible that SRIS scores would have changed if they were measured at a long term follow-up point when individuals would have had time to work with individuals in poverty and reflect back on their time in the simulation.

The results of this study need to be viewed in light of some limitations. Although we were able to improve participants' attitudes toward poverty and empathy levels, we do not know if these results would last over time. It would be helpful to measure APPP and TEQ scores at a long-term follow-up point. Additionally, we don't know how these changes in attitude affect clinical practice. Understanding of the clinicians (nurses, social workers, etc.) actual practices in handling patients who are in poverty after experiencing this simulation would be useful to assess through qualitative measures in future studies.

\section{Conclusion}


Through a simulated experience of living in poverty for a month, participating in the challenges that individuals in poverty conditions face, simulation participants' attitudes toward poverty and empathy levels improved. By participating in the simulation, nursing students and VA employees are now better prepared to tailor interventions to meet the daily challenges they understand their patients face. These findings have implications for clinical practice. Nurses need to understand how to help patients in poverty meet their health goals with limited resources and structural challenges. 


\section{References}

Ajzen, I., (2001). Nature and operation of attitudes. Annual Review of Psychology, 52, 27-58.

American Association of Colleges of Nursing (AACN). (2008). The essentials of baccalaureate education for professional nursing practice. Retrieved from http://www.aacn.nche.edu/education-resources/BaccEssentials08.pdf

Atherton, C. R., \& Gemmel, R. J. (1993). Measuring attitudes toward poverty: A new scale. Social Work Research \& Abstracts, 29(4), 28-30.

Bajaj, K., Meguerdichian, M., Thoma, B., Huang, S., Eppich, W., Cheng, A. (2018). The PEARLS Healthcare Debriefing Tool. Academic Medicine. 93(2), pg.336.

Brody, G.H., Yu, T., Chen, E. Miller, G.E., Kogan, S. M., \& Beach, S. R. (2013). Is resilience only skin deep? Rural African Americans' socioeconomic status-related risk and competence in preadolescence and psychological adjustment and allostatic load at age 19. Journal of Psychological Science, 24(7), 1285-1293. DOI: 10.1177/0956797612471954

Grant, A. M., Franklin, J., \& Langford, P. (2002). The self-reflection and insight scale: A new measure of private self-consciousness. Social Behavior and Personality, 30, 821-836.

Health Poverty Action. (2015). Key facts: Poverty and poor health. Retrieved from https://www.healthpovertyaction.org/info-and-resources/the-cycle-of-poverty-and-poorhealth/key-facts/

Hellman, A. N., Cass, C., Cathey, H., Smith, S. L., \& Hurley, S. (2018). Understanding poverty: Teaching social justice in undergraduate nursing education. Journal of Forensic Nursing, 14(1), 11-17. DOI: 10.1097/JFN.0000000000000182

Hu, T., Cox, K. A., \& Nyhof-Young, J. (2018). Investigating student perceptions at an international student-run free clinic serving marginalized populations. Journal of 
Interprofessional Care, 32(1), 75-79. https://doi.org/10.1080/13561820.2017.1363724

The Interprofessional Education Collaborative (IPEC). (2011). Core Competencies for Interprofessional Collaborative Practice: Report of an Expert Panel. Retrieved from https://www.aamc.org/download/186750/data/core_competencies.pdf

Johnson, A. M., \& Howell, D. M. (2017). International service learning and interprofessional education in Ecuador: Findings from a phenomenology study with students from four professions. Journal of Interprofessional Care, 31(2), 245-254. http://dx.doi.org/10.1080/13561820.2016.1262337

Loomis, J., \& De Natale, M. L. (2017). Teaching compassion for impoverished patients through simulation. Nursing 2017, 47(8), 20-23. DOI: 10.1097/01.NURSE.0000521039.35454.09

Menzel, N., Willson, L. H., \& Doolen, J. (2014). Effectiveness of a poverty simulation in Second Life: Changing nursing student attitudes toward poor people. International Journal of Nursing Education \& Scholarship, 11(1), 1-7. DOI: 10.1515/ijnes-2013-0076

Missouri Community Action Network (2016). Poverty Simulations. Retrieved from http://www.communityaction.org/povertysimulations/

Noone, J., Sideras, S., Gubrud-Howe, P., Voss, H., \& Mathews, L. R. (2012). Influence of a poverty simulation on nursing student attitudes toward poverty. Journal of Nursing Education, 51(11), 617-622. DOI: 10.3928/01484834-20120914-01

Patterson, N. \& Hulton, L. J. (2011). Enhancing nursing students' understanding of poverty through simulation. Public Health Nursing. DOI: 10.1111/j.1525.2011.00999.x

Reutter, L. I., Sword, W., Meagher-Stewart, D., \& Rideout, E. (2004). Nursing students' beliefs about poverty and health. Journal of Advanced Nursing, 48(3), 299-309. 
Roberts, C. \& Stark, P. (2008). Readiness for self-directed change in professional behaviors: Factorial validation of the Self-Reflection and Insight Scale. Medical Education, 42, 1054-1063.

Spreng, R. N., McKinnon, M. C., Mar, R. A., \& Levine, B. (2009). The Toronto empathy questionnaire: Scale development and initial validation of a factor-analytic solution to multiple empathy measures. Journal of Personality Assessment, 91(1), 62-71. DOI: $10.1080 / 00223890802484381$

Sword, W., Reutter, L., Meagher-Stewart, D., \& Rideout, E. (2004). Baccalaureate nursing students' attitudes toward poverty: Implications for nursing curricula. Journal of Nursing Education, 43(1), 13-19.

Turk, M. T., \& Colbert, A. M. (2018). Using simulation to help beginning nursing students learn about the experience of poverty. Nurse Education Today, 71, 174-179. https://doi.org/10.1016/j.nedt.2018.09.035

United Nations. (2019). Ending poverty. Retrieved from https://www.un.org/en/sections/issuesdepth/poverty/

United States Census Bureau. (2019). Income and poverty in the United States: 2018. Retrieved from https://www.census.gov/content/dam/Census/library/publications/2019/demo/p60266.pdf

Yang, K., Ratliff Woomer, G., Agbemenu, K., \& Williams, L. (2014). Relate better and judge less: Poverty simulation promoting cultural competent care in community health nursing. Nurse Education in Practice, 14, 680-685. 